Primljen / Received: 26.12.2018. Ispravljen / Corrected: 20.5.2019.

Prihvaćen / Accepted: 1.7.2019.

Dostupno online / Available online: 10.2.2020.

\section{Effects of addition of finely ground CRT glass on the properties of cement paste and mortar}

Authors:

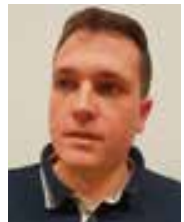

'Dušan Grdić, MSc. CE dusan.grdic@hotmail.rs Corresponding author

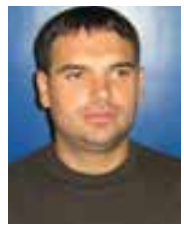

Assist.Prof. Nenad Ristić nenadristic82@gmail.com

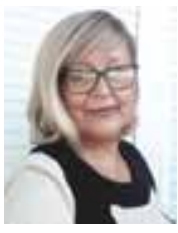

'Assoc.Prof. Gordana Topličic-Ćurčić gogatc@gmail.com

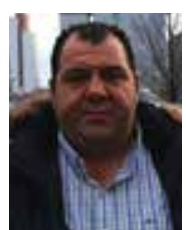

'Prof. Dragan Đordević dragance73@yahoo.com

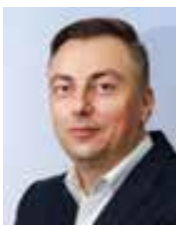

Assoc.Prof.Nenad Krstić nenad.krstic84@yahoo.com

${ }^{1}$ University of Niš, Serbia

Faculty of Civil Engineering and Architecture

2University of Niš, Serbia

Faculty of Science and Mathematics

Department of Chemistry
Original scientific paper

Dušan Grdić, Nenad Ristić, Gordana Topličić - Ćurčić, Dragan Đordević, Nenad Krstić

Effects of addition of finely ground CRT glass on the properties of cement paste and mortar

The paper presents test results for the cement paste and mortars, where a part of cement was replaced with finely ground cathode ray tube (CRT) glass. The following mass percentages of cement were replaced with glass: 5\%,10\%,15\%,20\% and 35\%. Two mortar series, with 5 and $10 \%$ of CRT in the total quantity of cement, were prepared. It was established that the presence of glass does not greatly affect the setting time and dimensional stability of the paste. Mortars with 5 and 10\% of CRT exhibited better mechanical properties compared to the reference mortar. All mortar series were found to be frost resistant.

\section{Key words:}

cement paste, mortar, CRT glass, pozzolanic activity, strengths, frost resistance, SEM analysis

Izvorni znanstveni rad

Dušan Grdić, Nenad Ristić, Gordana Topličić - Ćurčić, Dragan Đordević, Nenad Krstić

\section{Utjecaj dodavanja sitno mljevenog CRT stakla na svojstva cementne paste i morta}

U radu su prikazani rezultati ispitivanja cementne paste i morta kod kojih je određeni dio cementa zamijenjen sitno mljevenim katodnim staklom (CRT). Kao zamjena za cement korišteni su sljedeći maseni udjeli stakla: $5 \%$, 10\%, 15\%, 20 \% i $35 \%$. Izrađene su dvije serije morta s dodatkom 5 i 10 \% CRT stakla u odnosu na ukupnu količinu cementa. Utvrđeno je da prisutnost stakla ne utječe bitno na vrijeme vezivanja i postojanost volumena paste. Mortovi s 5 i 10 \% CRT stakla odlikovali su se boljim mehaničkim obilježjima u odnosu na referentni mort. Utvrđeno je da su sve serije morta otporne na utjecaj mraza.

Ključne riječi:

cementna kaša, mort, CRT staklo, pucolanska aktivnost, čvrstoće, otpornost na mraz, SEM analiza

Wissenschaftlicher Originalbeitrag Dušan Grdić, Nenad Ristić, Gordana Topličić - Curčić, Dragan Đordević, Nenad Krstić

Wirkung von feingemahlenem CRT Glas auf die Eigenschaften von Paste und Mörtel

In der Abhandlung werden die Ergebnisse der Untersuchungen der Zementpaste und des Mörtels dargelegt, bei denen ein bestimmter Teil des Zements durch feingemahlenes Kathodenglas (CRT) ersetzt wurde. Als Ersatz für den Zement wurden folgende Glasmasseanteile verwendet: 5\%, 10\%, 15\%, 20\% und 35\%. Angefertigt wurden zwei Chargen an Mörtel mit einem Zusatz von 5 und 10\% CRT Glas im Verhältnis zur Gesamtmenge an Zement. Festgestellt wurde, dass die Anwesenheit von Glas keine wesentliche Wirkung auf die Bindungszeit und die Beständigkeit des Pastavolumens hat. Die Mörtelchargen mit 5 und 10\% CRT Glas hatten bessere mechanische Eigenschaften im Vergleich zum Referenzmörtel. Festgestellt wurde, dass alle Mörtelchargen frostbeständig sind.

Schlüsselwörter:

Zementbrei, Mörtel, CRT Glas, Puzzolanaktivität, Festigkeit, Frostbeständigkeit, SEM Analyse 


\section{Introduction}

Sustainable construction industry, aimed at reducing negative impact on the environment, is one of key requirements in the contemporary civil engineering. From the beginning of the $21^{\text {st }}$ century, great efforts have been made in the field of civil engineering to use recycled materials that can replace at least a portion of traditional materials, in order to ensure the greatest possible level of compliance with fundamental principles of sustainable construction industry.

Thus, for instance, the use of ash obtained by burning wastewater sludge to replace a part of cement when making mortars and concrete was researched in the previous period [1]. Very encouraging results were obtained when testing the potential of using industrial by-products such as fly ash, ground masonry elements, and flotation tailing, in fabrication of the self compacting concrete (SCC). A mixture of SCC with flotation tailings had the highest density, while the mixture with waste tiles has proven to be excellent in terms of workability in fresh state as compared to other experimental mixtures [2]. One of good examples of sustainable concrete, described by Malešev et al [3], involved the use of fly ash as a replacement for a part of cement, and recycled aggregate as a replacement for natural aggregate. With a reduced water/cement ratio, the concrete of satisfactory mechanical properties was obtained.

Waste glass is another recycled mineral admixture whose potential for making cement composites is being actively researched. It can be used for preparation of cement mortars in two ways. The first option is to use it as fine aggregate, i.e. as a replacement for a certain amount of natural aggregate. The other option is to use the finely ground waste glass as a replacement for a part of cement when making mortar. One of the problems that can occur when using recycled glass aggregate for making cement composites is the occurrence of alkali-silicate reaction (ASR). Recycled glass has a high percentage of amorphous silicon (a glass bottle has around $70 \%$ ) which has a potential of reacting with alkali from cement, creating an ASR gel [4]. In case of a prolonged presence of moisture, this gel has a tendency to expand, which can initially cause cracks and, later on, complete destruction of hardened concrete. Current research has shown that the glass grain size has a considerable impact on the ASR reactivity of glass $[4,5]$. In the research presented in $[4,5]$, it was found that the size of cracks inside glass grains, occurring due to crushing and pulverization processes, determines the ASR reactivity. ASR occurs more readily when internal cracks are larger. On the other hand, a very finely ground powder does not cause the alkali - silicate reaction due to the presence of a small number of micro-cracks. The experimental research is focused exactly on testing the impact of finely ground glass as a replacement for a part of cement. In recent years, researchers have investigated the potential for using different types of waste glass: food processing industry glass containers, glass sludge which is a byproduct of glass polishing and processing, decorative crystal glass, TFT - LCD glass, etc.
Aliabdo et al. [6] replaced a portion of cement with finely ground glass containers and façade glass up to $25 \%$ of mass and monitored the impact on the properties of the cement paste made in this way. It was found that, when the share of replacement of cement with glass increases, the quantity of water needed for standard consistency decreases and the added glass has no noticeable impact on the setting time and soundness of cement paste. Mafalda A. Matos et al. [7] tested the mechanical strength and durability of mortar where up to $20 \%$ was replaced with ground glass from windshields and commercial glass containers. At 7 and 28 days of age, the compressive strength of mortars with the addition of glass is lower compared ot reference samples. However, at 90 days, the tests proved that the mortar with $10 \%$ of glass attained the reference strength, whereas the mortar with 20 $\%$ of glass had even higher values of compressive strength than the reference mortar. The addition of glass improved mortar durability in terms of alkali - silicate reactivity, sulphate action and chloride penetration. Yung - Wang et al [8] examined the impact of the replacement of a part of cement up to $50 \%$ by mass, using ground TFT-LCD glass. The increase of the share of replacement of cement with this type of glass yielded a uniform reduction of the compressive strength of mortar.

CRT glass represents a considerable portion of electronic waste (e-waste). E-waste quantity increases at a considerably higher rate than other types of solid waste in the world. According to the data of the United Nations University, out of 41.8 million tons of e-waste generated globally in 2014, 6.3 million tons were television and computer CRT screens [9]. Selling of CRT devices reached a record of 20 million units in 1996. Since then, there has been a gradual decline of sales, due to the emergence of new TFT-LCD screens, and the sales actually halved ten years later. Nowadays, no CRT screens are being sold, but people still own many such devices. It is estimated that annually the landfills of Europe receive between 50 and 150 thousand tons of obsolete CRT screens [10].

The goal of this research is to prove the potential for using the finely ground CRT glass as a supplement for a part of cement used for making mortars (and concretes). The research was conducted in order to find the highest possible quantity of replacement of cement with recycled glass. At that, mortar properties must be such to ensure its proper practical use in civil engineering. This would represent a contribution to solving the environmental problem of safe disposal of CRT screens, while also enabling financial savings.

\section{Materials and methods}

\subsection{Cathode ray composition and recycling process}

There are two types of cathode ray tubes: monochromatic tubes and colour tubes. Three basic glass elements of a CRT screen are: neck glass, funnel glass, and panel glass. Their mass share 
differs, and it amounts to: $1 \%, 33 \%$ and $66 \%$, respectively. The neck, even though having a small share in the mass of a screen, contains $25 \%$ of lead, which is much more compared to other elements. The funnel is the largest part of a cathode ray tube and it contains around $20 \%$ of lead. The panel is the front, visible part of the cathode ray and it contains almost no lead (0 - $3 \%$ ). The panel is coated with layers of barium and strontium whose role is to protect the viewers from hazardous effects of the UV and $\mathrm{X}$-ray radiation created by electron gun [11]. The panel and a part of the funnel are joined with lead frit.

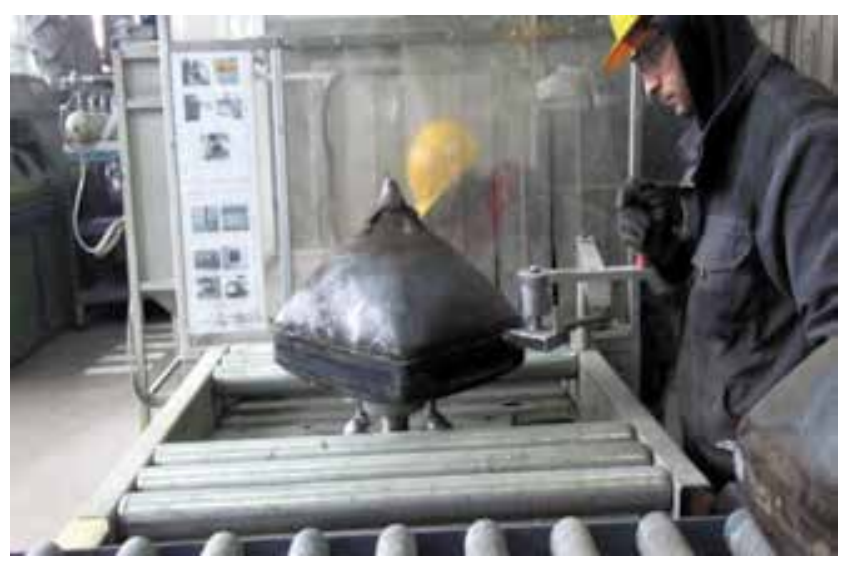

Figure 1. Automatic separator for separation of CRT devices in local recycling centre

Considering that CRT glass is classified as hazardous waste because of its chemical composition, its transport and disposal must be operated in accordance with special regulations. There are two possible recycling systems: an open and a closed recycling loop. The closed loop involves the use of old CRT screens in the production of new screens. Considering that new CRT screens are no longer manufactured anywhere in the world, the closed recycling loop has ceased to be an option. On the other hand, an open loop comprises usage of an old CRT screen for manufacturing

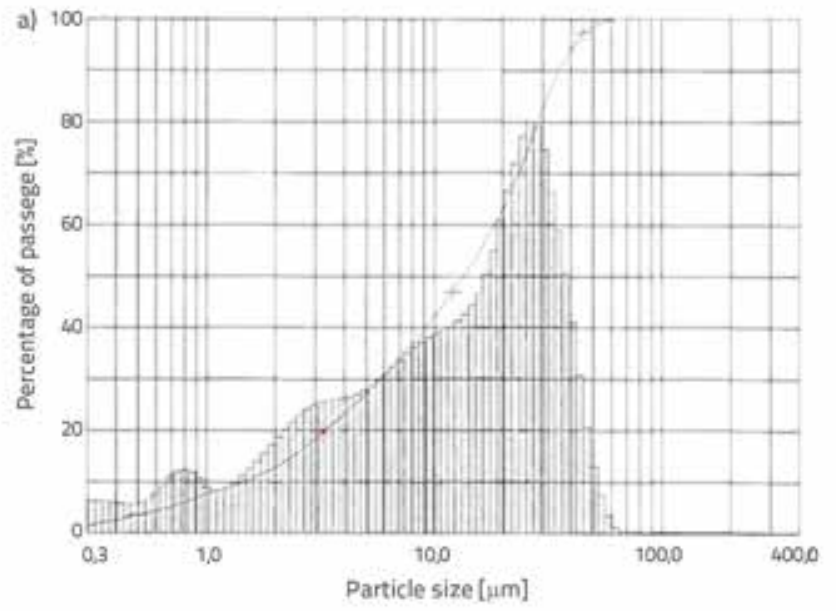

of a new product different from the original one. In the case of an open recycling loop, the first step is to break the screen down to its basic components. The panel glass is most often separated from the funnel glass using: Hot Band Technology, Diamond Saw Method, and Laser Cutting System. The panel glass used in this experiment was obtained using the hot band technology for the separation of basic CRT components. Essentially, this method involves heating the joint between the panel and funnel glass, which results in controlled separation. Figure 1 shows a separator at the local recycling system in Niš where CRT screens are dismantled and where the described CRT screen dismantling method is used.

\subsection{Materials}

The Ordinary Portland cement CEM I 52.5R, manufactured by " $\mathrm{CRH}$ " Novi Popovac, complying with all quality requirements specified in SRPS EN 196-1:2018, SRPS EN 196-3:2017, SRPS EN 196-6:2011 and SRPS EN 197-1:2013, was used for making cement pastes and mortars. The particle size distribution of cement is presented in Figure $2 a$. The $0 / 4 \mathrm{~mm}$ fraction of aggregate originating from the South Morava river was used. The CRT glass came from the Niš based recycling centre "Jugo - Impex E.E.R." d.o.o. Large shards of CRT glass were ground using a laboratory ball mill so that glass could pass through the $0.063 \mathrm{~mm}$ sieve with no residue. Such finely ground glass had a density of $2.84 \mathrm{~g} / \mathrm{cm}^{3}$ and the Blaine specific surface area of $2450 \mathrm{~cm}^{2} / \mathrm{g}$. Chemical composition of glass was determined using the Bruker XRF wavelength dispersive device, as shown in Table 1. The particle size distribution for cement and CRT glass was determined using the laser particle size analyser CILAS 920 in humid environment in isopropyl alcohol, as shown in Figure 2. More than $63 \%$ of glass grains were finer than $36 \mu \mathrm{m}$, while $42 \%$ were finer than $20 \mu \mathrm{m}$ Around $25 \%$ of cathode glass particles were finer than $10 \mu \mathrm{m}$ Tap water was used for making experimental types of mortar. Chemical admixtures were not used.

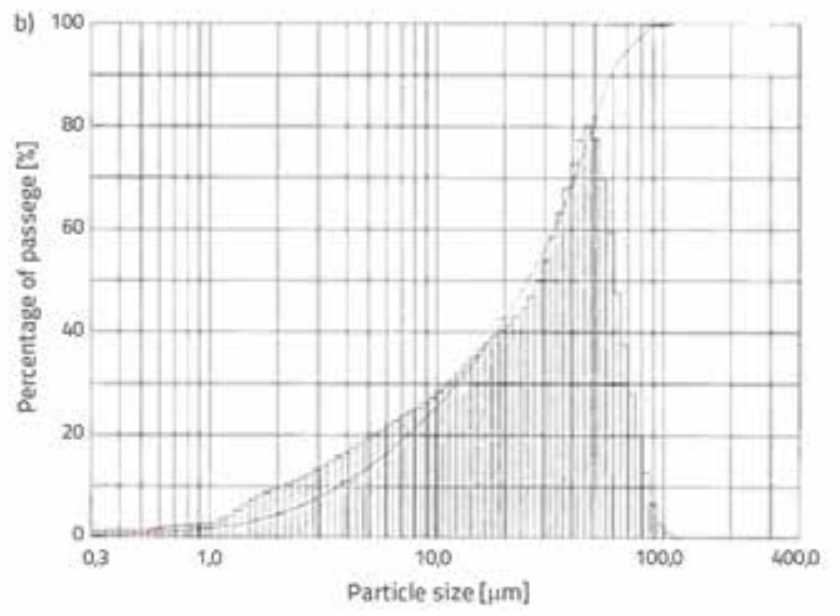

Figure 2. Particle size distribution of: a) cement CEM I 52.5R; b) CRT glass 
Table 1. Chemical composition of CRT glass

\begin{tabular}{|l|c|c|c|c|c|c|c|c|}
\hline $\begin{array}{l}\text { Chemical } \\
\text { compound } \\
{[\%]}\end{array}$ & $\mathrm{SiO}_{2}$ & $\mathrm{Al}_{2} \mathrm{O}_{3}$ & $\mathrm{Fe}_{2} \mathrm{O}_{3}$ & $\mathrm{CaO}$ & $\mathrm{MgO}$ & $\mathrm{K}_{2} \mathrm{O}$ & $\mathrm{Na}_{2} \mathrm{O}$ & $\mathrm{TiO}_{2}$ \\
\hline CRT glass & 60.61 & 2.88 & 0.58 & 1.31 & 0.53 & 6.45 & 7.61 & 0.30 \\
\hline CEM I 52,5 R & 19.30 & 4.28 & 2.87 & 62.8 & 2.20 & 0.91 & $0 ., 21$ & - \\
\hline
\end{tabular}

Mineralogical - petrographic analysis of the aggregate revealed that it is mostly composed of metamorphic rocks, with a small portion of igneous and sedimentary rocks. Most tested aggregate proved to be quartz, with the presence of feldspar, amphibole - pyroxene and mica. Therefore, the aggregate does not contain mineral constituents that could adversely affect physical and mechanical properties of concrete. Also, it does not contain elements that can be potentially reactive in concrete, or prevent hydration of cement, or cause reinforcement corrosion. Therefore, from the aspect of mineralogical - petrographic aggregate composition, it can be considered suitable for the preparation of mortars and concretes.

\subsection{Plan and program of testing}

This experimental research can be divided into two phases. In the first phase, the glass pozzolanic activity was tested (SRPS B.C1.018:2015), and the impact of replacement of a part of cement with finely ground CRT glass on cement paste properties was determined. In this phase of testing, a special ball mill was constructed (Figure 3a) so that the CRT glass can be efficiently ground to the desired fineness of less than 0.063 $\mathrm{mm}$ (Figure 3b). After confirming pozzolanic activity of the glass, a total of six types of cement pastes were prepared. In addition to the reference paste $\mathrm{E}$ (without CRT glass), five pastes were made with $5 \%, 10 \%, 15 \%, 20 \%$ and $35 \%$ of finely ground glass as replacement of cement. The percentage of replacement of cement with glass was measured in relation to the mass of cement. The cement paste was tested for standard consistency, setting time and soundness according to the SRPS EN 1963:2017.

A total of eight mortar mixtures were tested in the second phase of the experiment. The following mixtures were made: mortar without glass (E), five mortar mixtures with the same percentage of glass replacement as in the cement paste, and two mortars with $5 \%$ and $10 \%$ of glass. Mortar was tested as follows: consistency on flow table (SRPS B.C8.050:1981), entrained air content (SPRS B.C8.050:1981), hardened mortar density (SRPS ISO 6276:1997), compressive and flexural strength (SRPS EN 196-1:2017), frost resistance (SRPS U.M8.002:1997), shrinkage (SRPS B.C8.029:1979), alkali silicate reactivity (ASTM C227-10) and SEM analysis.

Mortar mixtures were made according to SRPS EN 196-1:2017. Prior to mortar preparation, the cement and ground glass mixture was homogenized by mixing for five minutes in a mixer at 2500 revolutions per minute in a hermetically closed vessel. The Hobart N-50 laboratory mixer was used for the preparation of mortar. After pouring mortar into moulds, the samples were cured for $24 \mathrm{~h}$ in water bath (temperature: $20^{\circ} \mathrm{C}$, air humidity: $95 \%$ ) and then they were demoulded and kept in water at $20^{\circ} \mathrm{C}$ until testing.

Testing of pozzolanic activity, physical, mechanical and rheological properties of mortar was conducted on prisms measuring $40 \times 40 \times 160 \mathrm{~mm}$. The alkali - silicate reactivity was tested on mortar prisms measuring $25 \times 25 \times 285 \mathrm{~mm}$.

\subsection{Composition of mortar mixtures}

The composition of mortar mixtures is shown in Table 2. A constant binder (powder) to sand ratio of 1:3 was used, except for mortars WGA5 and WGA10. A constant water/binder ratio of 0.50 was used for the reference mortar and for the mortar where cement was replaced with glass. In glass containing mortars, the water/binder ratio varied depending on the percentage of glass, i.e. it was 0.48 for the mortar with $5 \%$ of glass, and 0.45 for the mortar with $10 \%$ of glass, which was done to preserve

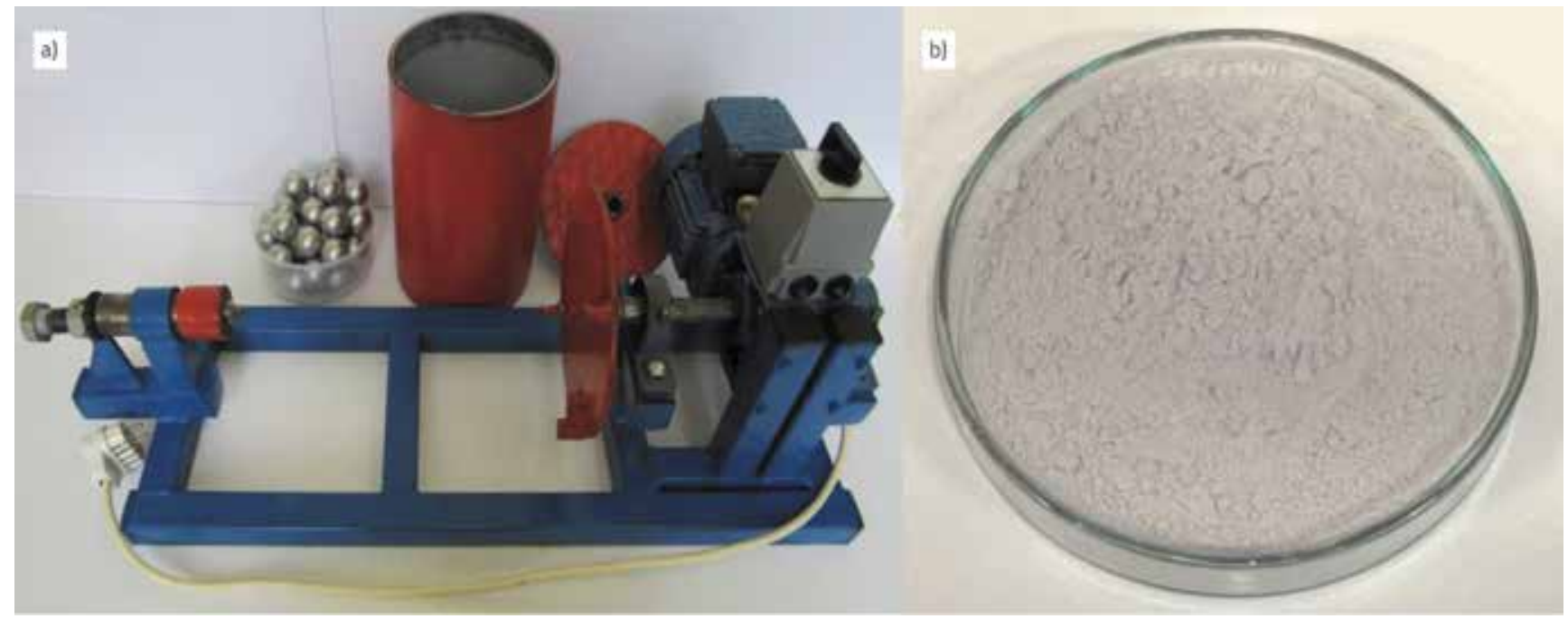

Figure 3. a) laboratory ball mill for glass grinding; b) homogenized cement and CRT glass mixture 
Table 2. Composition of experimental mortar mixes with different share of CRT glass

\begin{tabular}{|c|c|c|c|c|c|c|c|c|}
\hline \multirow{2}{*}{ Composition } & \multicolumn{8}{|c|}{ Mortar mark } \\
\hline & $\mathbf{E}$ & WG5 & WG10 & WG15 & WG20 & WG35 & WGA5 & WGA10 \\
\hline Mass of cement [g] & 450.0 & 427.5 & 405.0 & 382.5 & 360.0 & 292.5 & 450.0 & 450.0 \\
\hline Mass of glass [g] & - & 22.5 & 45.0 & 67.5 & 90.0 & 157.5 & 22.5 & 45.0 \\
\hline Mass of aggregate $0 / 4 \mathrm{~mm}$ [g] & 1350 & 1350 & 1350 & 1350 & 1350 & 1350 & 1350 & 1350 \\
\hline Mass of water $[\mathrm{g}]$ & 225 & 225 & 225 & 225 & 225 & 225 & 225 & 225 \\
\hline Water/binder ratio w/b & 0.50 & 0.50 & 0.50 & 0.50 & 0.50 & 0.50 & 0.48 & 0.45 \\
\hline
\end{tabular}

the equal consistency of all mortars. Mortar mixtures were marked as WG which is abbreviation of waste glass, while the letter A stands for addition of glass, while the number denotes percentage of replacement/addition of ground glass.

\section{Experimental tests and discussion of results}

\subsection{Physical and chemical characteristics of glass}

The FTIR spectrum of one of CRT glass samples is shown in Figure $4 \mathrm{a}$. The recording of the FTIR spectra was carried out at the Faculty of Technology in Leskovac. The FTIR analysis of the samples was made in the area 4000 to $400 \mathrm{~cm}^{-1}$, at a resolution of $2 \mathrm{~cm}^{-1}$, using the BOMEM Michelson Hartman \& Braun Series MB spectrometer. The absorption band of about $3400 \mathrm{~cm}^{-1}$ and $1650 \mathrm{~cm}^{-1}$, showing that only a small amount of water is present in the glass, can be attributed to the stretching and bending vibration of either free $\mathrm{OH}$ groups or free $\mathrm{H}_{2} \mathrm{O}$ molecules. The water had no substantial effect on glass structure. It is also often reported that bands within the 900 to $1100 \mathrm{~cm}^{-1}$ range are composite features of $\mathrm{Si}-\mathrm{OH}$ species. Therefore, the strong band at the frequency of $\sim 800 \mathrm{~cm}^{-1}$ was assigned to stretching vibration of Si-OH. The peak near $450 \mathrm{~cm}^{-1}$ and a low frequency peak near $700 \mathrm{~cm}^{-1}$, were assigned to $\mathrm{Si}-\mathrm{O}-\mathrm{Si}$ out of plane bending and $\mathrm{Si}-\mathrm{O}-\mathrm{Si}$ stretching modes, respectively.

XRD diffractograms of one of the analysed CRT glass samples are presented in Figure 4a. The XRD method was used for determination of mineral composition of investigated samples using the apparatus GNR Explorer. Peak $2 \theta$ degree positions at about 19.0496, 29.6040, 40.7237, and 50.1789, with the maximum relative intensity at 29.6040 , clearly point to the presence of $\mathrm{SiO}_{2}$ (quartz) in samples. Peaks from the XRD diffractogram are indicative of the presence of amorphous $\mathrm{SiO}_{2^{\prime}}$ whereby the prominent peak at 40 points to the presence of $\mathrm{SiO}_{2}$ in the crystal form, too.

The average compressive strength value of 5,82 MPa was obtained based on test results for pozzolanic activity of finely ground glass on lime mortar according to the SRPS B.C1.018:2015. It can be concluded that the experimental glass is pozzolanically active, and that its class is 5 .

\subsection{Impact of replacement of cement with CRT glass based on properties of cement paste}

The impact of cement replacement with CRT glass on standard consistency of cement paste is presented in Figure 5a. It can be unequivocally concluded that the need for water required for achieving the paste of standard consistency declines as the share of added glass increases. As it is well known, glass does not absorb water, which may explain this trend. On the other hand, it was not found that glass addition has a considerable influence on the initial and final setting time (Figure 5b). In all experimental pastes, the setting starts after 180 minutes on an average, while the setting ends after 210 minutes. All cement
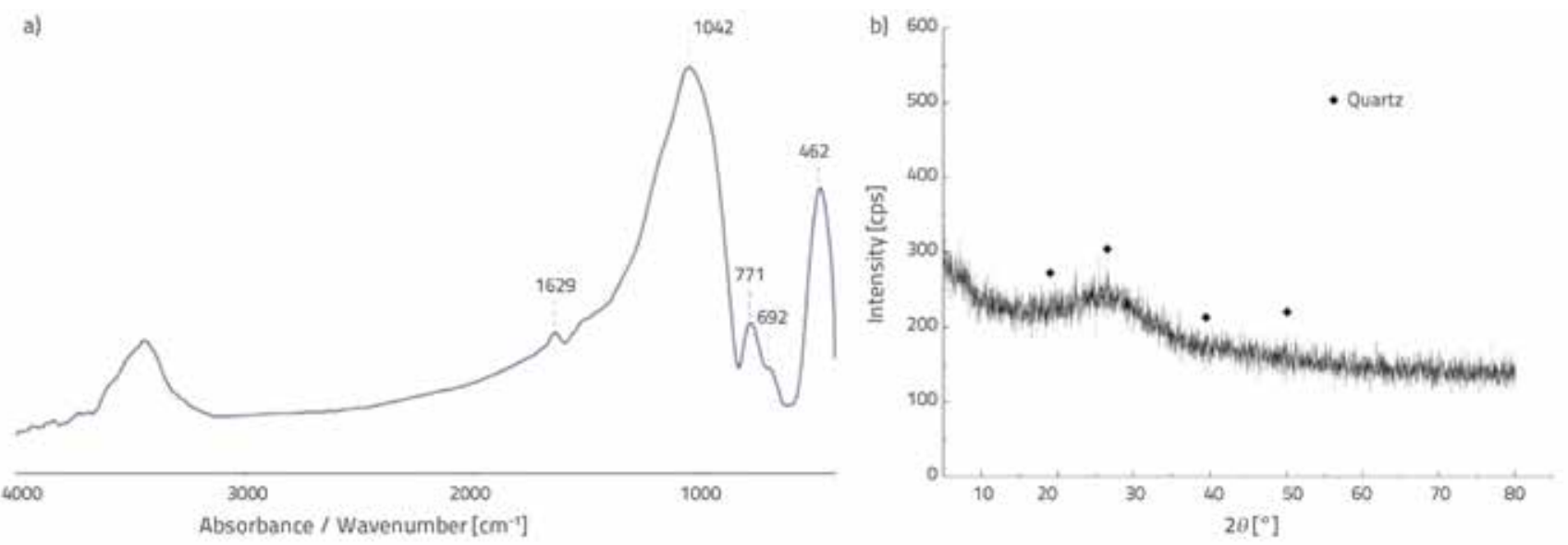

Figure 4. a) FTIR spectra of experimental CRT glass; b) XRD diffractogram of CRT glass 

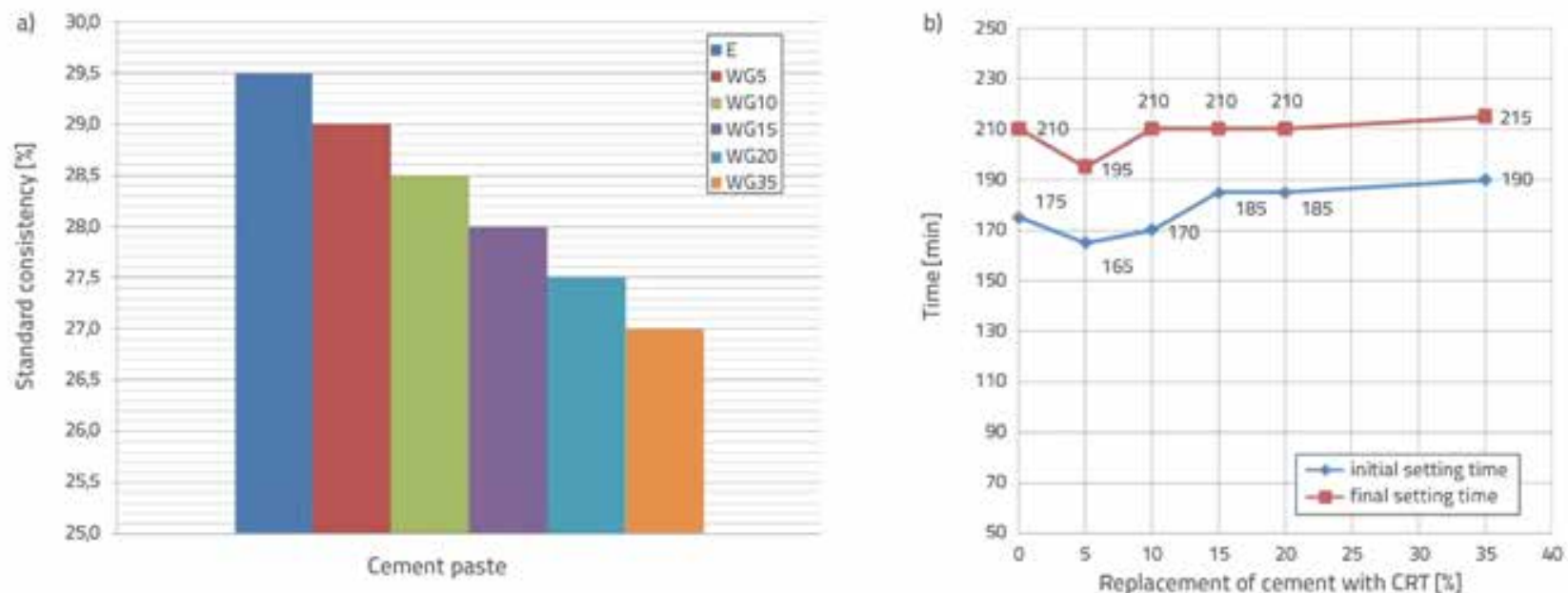

Figure 5. a) impact of replacement of a part of cement with CRT glass on standard consistency of cement paste; b) setting time of cement paste with different shares of CRT glass

pastes have a constant volume. The standard consistency test results are in good agreement with the results obtained in [9]. It is stated in [9] that, for making paste of standard consistency, there is a decrease of water/cement ratio for an average of $0,7 \%$ at each $10 \%$ of glass added. A similar result in terms of paste setting time was obtained by Kamali et al. [12] who used pulverized glass containers, with maximum 20 percent of cement replacement.

\subsection{Impact of replacement of cement with CRT glass and addition of glass on fresh mortar properties}

Figure 6a shows the impact of various levels of replacement, i.e. the impact of addition of CRT glass on mortar flow value on flow table, while the impact of the presence of glass on the share of entrained air in mortar is shown in Figure 6b. By measuring mortar flow, it was found that there is no considerable impact of replacement/addition of glass on the variation of mortar consistency. Thus, the average flow value was around $125 \mathrm{~mm}$.

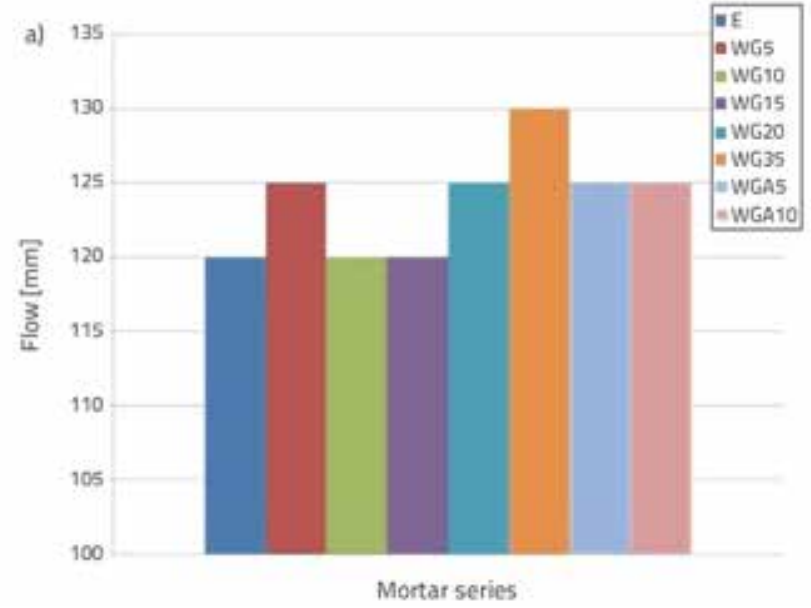

The amount of entrained air was around $8 \%$ for all mortars. A slight variation of entrained air value of mortars WG5 and WG20 cannot be considered relevant, and can partly be attributed to technical characteristics of porosimeter. In general, there is no major change of fresh mortar properties up to $35 \%$ of cement replacement with glass. The results of consistency testing agree well with the data found in literature [7].

\subsection{Impact of replacement of cement with CRT glass, and addition of glass on properties of hardened mortar}

The effects of replacement/addition of CRT glass on the change of compressive strength of mortar at the age of 2, 7, 28 and 90 days are presented in Figure 7. Along with the increase of the share of replacement of cement with CRT glass, there is the reduction of compressive strength of mortars. After a statistic analysis of data, it was concluded that the reduction of compressive strength is a logarithmical function with a

Figure 6. a) Flow value of mortars; b) content of entrained air in fresh mortars

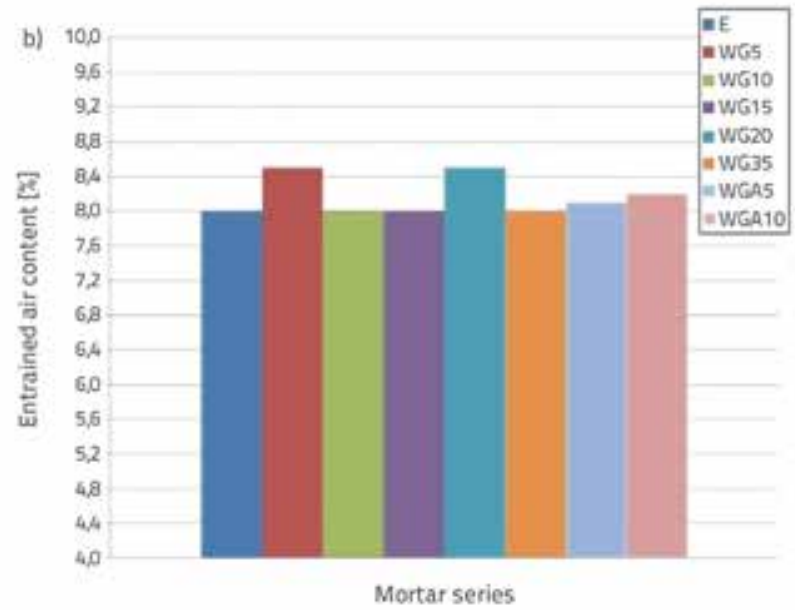



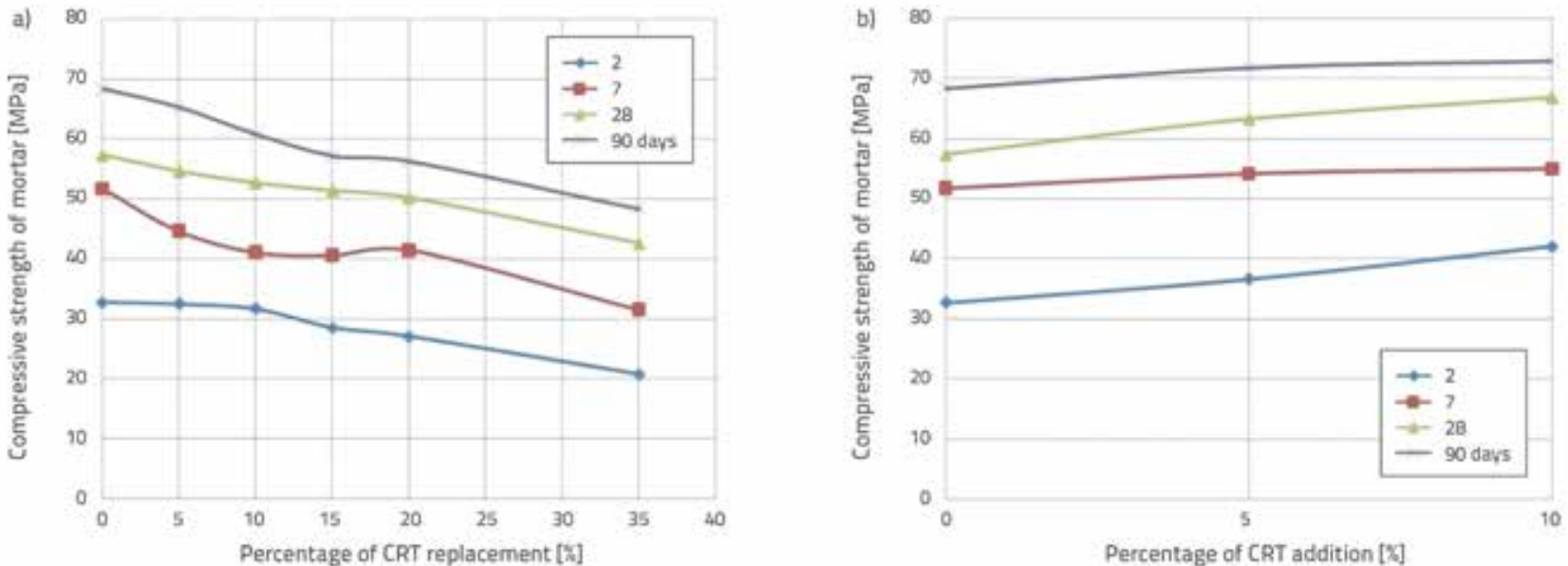

Figure 7. Variation of compressive strength of mortar at the ages of 2, 7, 28 and 90 days as a function of: a) percentage of replacement; b) addition of CRT glass
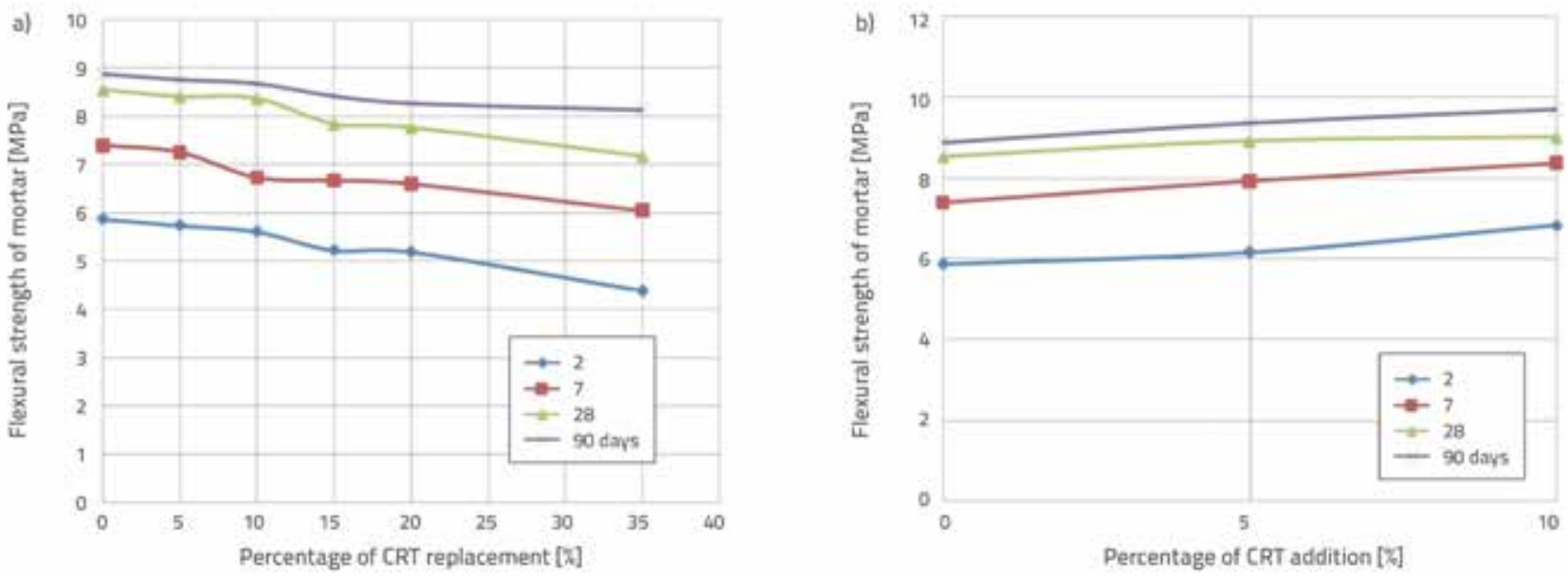

Figure 8. Variation of flexural strength of mortar at the ages of 2, 7, 28 and 90 days as a function of: a) percentage of replacement; b) addition of CRT glass

high degree of correlation (exceeding 0.94 for all mortars). The highest drop of strength is present in the mortars WG20 and WG35 at early strength tests, too. For instance, the tests of mortar WG35 after 2 and 7 days show that the compressive strength reduces by $36.58 \%$ and $39.01 \%$, respectively, compared to the reference mortar. After that period, the difference in the strength of the reference mortar and mortars where cement was replaced with glass is slightly lower. In the case of the mentioned mortar WG35, at the tests after 28 and 90 days, the strength reduction is $25.61 \%$ and $29.16 \%$, respectively. In the literature, this trend of a "delayed" increase in strength of mortars with finely ground glass is explained by the nature of the pozzolanic activity process. The mortars WGA5 and WGA10 had higher compressive strengths than the reference mortar at all ages. At the tests after 90 days, the mortars with the addition of $5 \%$ and $10 \%$ of glass on the entire amount of cement had $5.04 \%$ and $6.54 \%$ higher compressive strength compared to the reference mortar, respectively.

Finely ground glass reduces the flexural strength of mortar considerably. The variation of flexural strength of mortar at the ages of $2,7,28$, and 90 days as a function of percentage of replacement and addition of CRT glass to mortar is presented in Figure 8. It is important to mention that only a slight drop of flexural strength at 90 day tests has been observed in case of up to $15 \%$ of cement replacement with glass. The highest decline of strength has been observed in the WG35 but, in this case, it is not a major decline - only $8.45 \%$ in comparison with the reference mortar. The flexural strength of mortars WGA5 and WGA10 at maximum age is by $5.41 \%$ and $9.23 \%$ higher compared to the reference mortar. It can be definitively concluded that mechanical properties of mortar are improved at up to $10 \%$ of addition, while there is no considerable degradation of compressive and flexural strength in the case of up to $15 \%$ replacement with glass. The results obtained by testing mechanical properties are in agreement with the results of similar tests presented in $[7,8]$.

The highest decline in compressive strengths after 25 cycles of alternating freezing/thawing of mortar was measured in mortars WG20 and WG35 and it amounted to $10.16 \%$ and 11.82 $\%$, respectively. Yet, all the mortars can be considered durable 

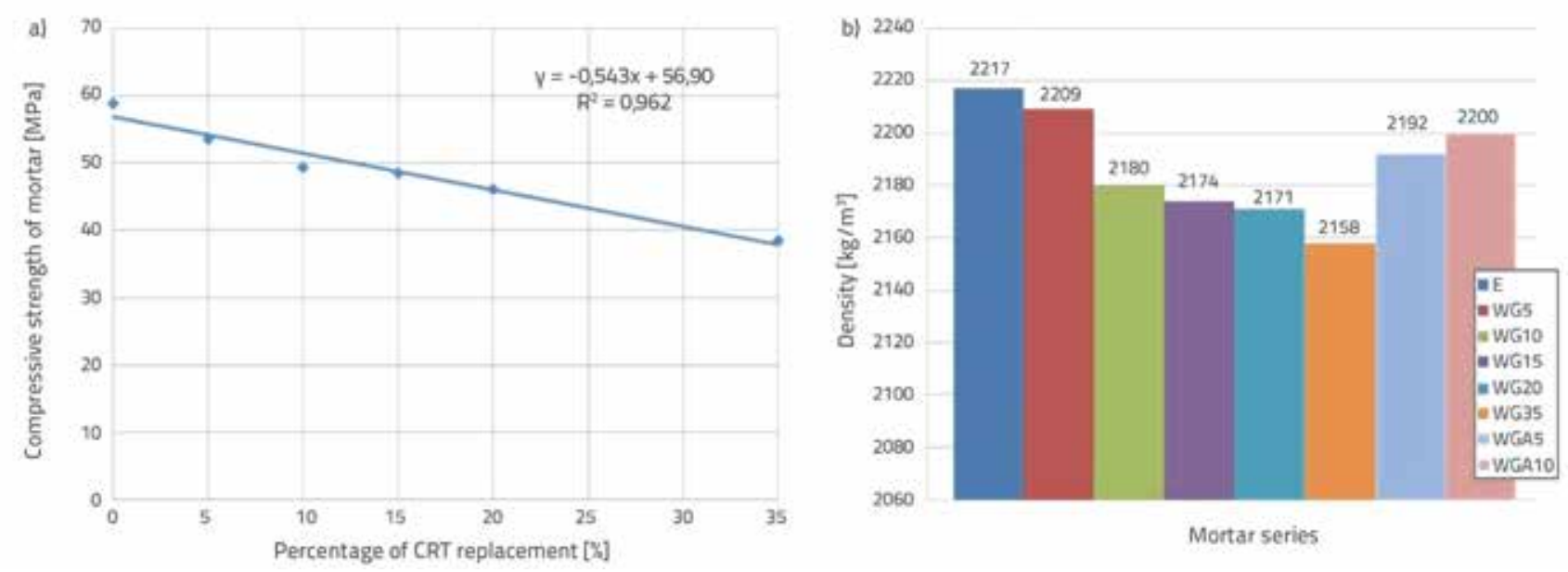

Figure 9. a) variation of compressive strength of mortar after 25 cycles of frost action as a function of the percentage of replacement of CRT glass in mortar, b) Density of hardened mortar in water saturated state

in terms of this type of action, as no reduction of compressive strength higher than $25 \%$ was recorded. In the mortar where a part of cement was replaced with CRT glass, it can be concluded that the decline of strength in comparison to the reference mortar increases with an increase in glass content in mortar. However, as already mentioned, this variation is within permissible limits. The mortars WGA5 and WGA10 exhibited, just like the reference mortar, a slight reduction in compressive strength after the tests. Variation of mortar strength after 25 cycles of freezing/thawing action as a function of percentage of replacement of Portland cement with recycled glass is presented in Figure 9a, where it can be seen that it is a linear function with a high degree of correlation.

The density of hardened mortar in water saturated state was measured immediately prior to the start of frost resistance testing (Figure 9b). It was established that replacement of cement with ground glass has no considerable impact on the variation in mortar density. In mortar WG35 reduction of density is 2.66 $\%$ in comparison to the reference mortar, while the mortars with addition - WGA5 and WGA10 - have approximately the same density as the reference mortar. Such a small impact of the addition of glass on the density of mortar can be explained in the following way: the specific gravity of cement is $3.15 \mathrm{~g} / \mathrm{cm}^{3}$ and, in the case of glass, it is $2.84 \mathrm{~g} / \mathrm{cm}^{3}$. Therefore, regarding the total amount of material in $1 \mathrm{~m} 3$ of mortar and considering the small differences in specific gravity of these two materials, a negligible impact of addition of glass on the density of hardened mortar is expected.

The shrinkage of mortar in air was monitored in a year-long interval. Variation in the length of mortar prisms was measured at the mortar age of $3,7,14,21,28,90,180$, and 360 days. The test results are given in Figure 10. In the first 7 days after preparation of mortar, when shrinkage is the most intensive, a very uniform shrinkage is exhibited by the reference mortar and mortars with up to $20 \%$ of replaced cement. In the case of mortars in which cement was replaced with CRT glass, the shrinkage exhibited in the mentioned period by the mortar WG35 was two times lower than that of the reference mortar.
The decisively lowest shrinkage in the first 7 days was observed in mortar WGA5 where the shrinkage is barely noticeable, whereas the mortar WGA10 has a result that is equally good to the one obtained for mortar WG35. At the age of 28 days, the mortars with up to $15 \%$ of replaced cement were equal to the reference mortar, while the shrinkage of mortars WG20 and WG35 was by $16.13 \%$ and even $40.32 \%$ lower, respectively, compared to the reference mortar. At this age, the lowest shrinkage was measured in WGA5 mortar, i.e. it was as low as $0.33 \mathrm{~mm} / \mathrm{m}$. A similar trend in terms of glass impact on shrinkage of mortar was observed during the tests at 90,180 , and 360 days. During the tests at 360 days, the mortars WG20 and WG35 exhibited the lowest shrinkage, which was by 18.28 $\%$ and $27.96 \%$ lower, respectively, compared to the reference mortar. The mortars with the addition of glass had uniform shrinkage at 360 days, and around $20 \%$ lower shrinkage than the reference mortar. The obtained results partially agree with the results of Her-Yung Wang [8]. Wang concluded that the lowest shrinkage was observed in the mortar with $20 \%$ of cement replaced by TFT - LCD glass, while in the cases when the replacement was higher than $30 \%$, the shrinkage of such mortars approached the shrinkage value of reference mortar, or even slightly exceeded it.

In general, it can be concluded that the mortar shrinkage declines with an increase in cement replacement with glass in mortar. The lowest shrinkage was measured for the WG35. The addition of 5 and 10 percent of CRT glass reduces mortar shrinkage by around $20 \%$. The final conclusion is that the presence of CRT glass in mortar reduces mortar shrinkage in air.

The alkali - silicate reactivity of glass was measured on the reference mortar and on the mortar with the highest percentage of replacement of cement with CRT glass - WG35. The measurement was conducted in full accordance with ASTM C227. By measuring the expansion of mortar prisms, it was determined that mortar WG35 had lower variation of volume as related to reference mortar at all ages, despite the fact that glass contained a considerable amount of amorphous silicon 
dioxide. Also, the final value of volume variation is far below the boundary value of $+0,10 \%$ that is defined in ASTM C33/C33M13. An explanation of such phenomenon can be found in [7]. Free silicon in glass powder, which is an amorphous material, will be quickly consumed during the pozzolanic reaction, and it will react with other compounds to form a mineral phase. In this way, the dissolved silicon dioxide will be included in the crystal grid of cement gel and it will not be available for the process of alkali-silicate reaction which would normally occur quite later than the pozzolanic reaction [7].

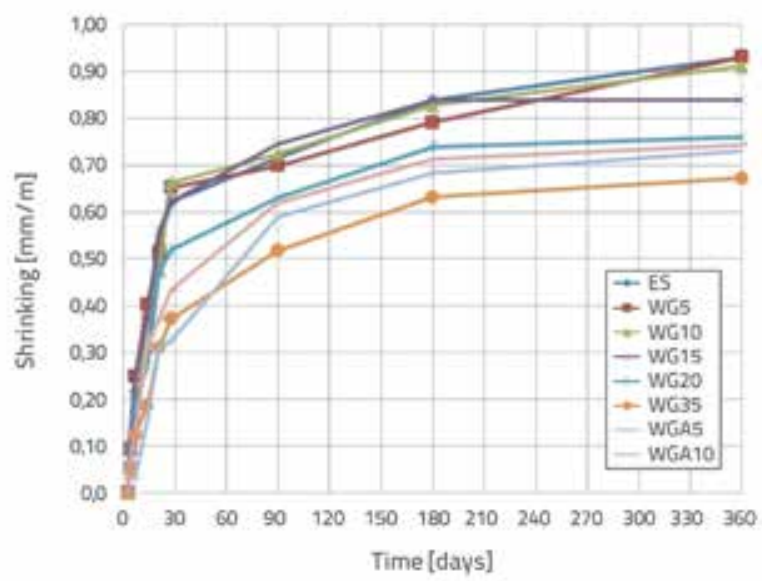

Figure 10. Shrinkage of mortars at the ages of 3, 7, 14, 28, 90, 180, and 365 days

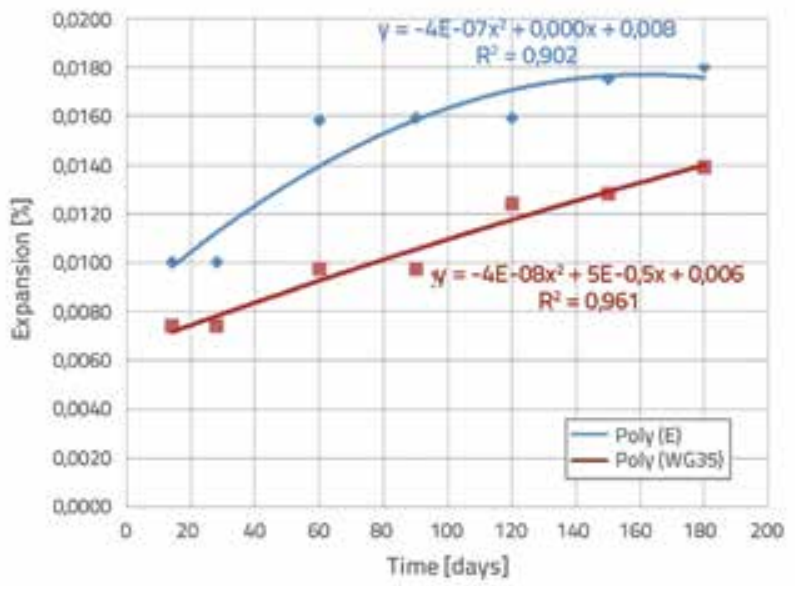

Figure 11. Testing of alkali-silicate reactivity of finely ground CRT glass

Waste glass particles are generally known to have a dual behaviour in mortars: they enter into a pozzolanic reaction which produces
C-S-H compounds whose content of calcium is high and alkali is low, or an ASR reaction where the contents of alkali is high, and calcium is low [4]. One of the ways to avoid an ASR reaction is to make waste glass particles smaller than $300 \mu \mathrm{m}$ [5]. Figure 12e shows the appearance of pulverized CRT glass, with a 200 times magnification, using the electronic microscope JEOL JSM 5300, USA. It can be noticed that the glass particle size ranges between several micrometers to around $100 \mu \mathrm{m}$. This particle size ensures that the reaction is primarily pozzolanic which is good for mechanical properties of mortar. The texture of the reference mortar is compact, slightly homogenous and in some areas almost flat (Figure 12.a). In the case of mortar WG20, the texture compactness is lost; it becomes more porous and rough, with clearly observable grains of ground glass (Figure 12.b). In the case of mortar with maximum share of glass, WG35, the texture becomes rougher and more porous (Figure 12.c). By adding $10 \%$ of ground glass in relation to the mass of cement (WGA10), the texture of the obtained concrete does not differ much from the reference mortar texture, and so it can be stated that ground glass particles are well bound with other mortar components in the given conditions of preparation (Figure 12.d).

\section{Conclusion}

Based on experimental results, a number of conclusions can be drawn about the impact of replacement/addition of ground CRT glass on the properties of cement paste and mortar.

- A class 5 pozzolanic activity was established by analysis of physical and chemical results of CRT glass.

- Peaks shown on XRD diffractogram point to the presence of amorphous $\mathrm{SiO}_{2}$, whereas a prominent peak at 40 is indicative of the presence of $\mathrm{SiO}_{2}$ in the crystal form.

- Increase in replacement of cement with ground glass reduces the amount of water necessary for achieving the standard paste consistency.

- The research did not found a noticeable impact of glass on the setting time and soundness of cement paste.

- By measuring mortar flow on the flow table, it was found that the presence of glass does not have a noticeable impact on the variation of mortar consistency.

- The entrained air content, amounting to approximately $8 \%$, is uniform in all mortar mixtures.

- The compressive strength of mortar decreases at all ages with an increase in the percent of cement replacement with CRT glass. The highest drop of strength is present in the mortars with the highest share of glass, WG20 and WG35 at early strength tests at 2 and 7 days. After that period, the difference
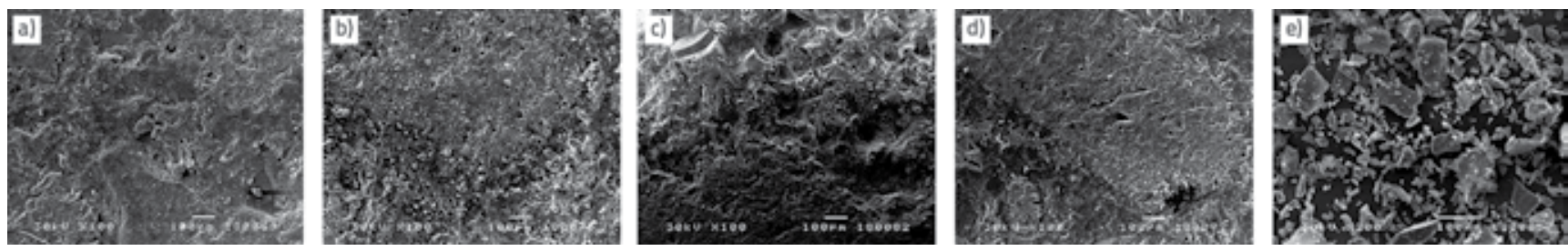

Figure 12. SEM mortar analysis: a) reference mortar; b) WG20; c) WG35; d) WGD10; e) pure CRT glass 
in strength of reference mortar and mortars where cement was replaced with glass is slightly lower. In literature, this trend of "delayed" increase in mortar strength with glass addition is explained by the nature of pozzolanic activity of glass.

- Mortars with the addition of glass WGA5 and WGA10 exhibited a higher compressive strength than the reference mortar at all ages; thus, at tests conducted after 90 days, their respective compressive strengths were by $5.04 \%$ and $6.54 \%$ higher in relation to the reference mortar.

- Replacement of cement with up to $15 \%$ of glass causes a slight decrease in flexural strength at 90 days. The highest drop of flexural strength is recorded for mortars with $35 \%$ of replacement of cement with glass but, even in this case, the reduction is not considerable - only $8.45 \%$.

- Mortars with addition of glass exhibit better flexural strength results compared to reference mortar.

- All mortars can be considered durable in terms of frost action; in this respect, no reduction of compressive strength higher than $25 \%$ was recorded.

- It was established that the replacement of cement with CRT glass does not have a noticeable impact on the variation of density of hardened mortar in the water saturated state; this is quite expected, considering the values of specific gravity of cement and ground CRT glass and the share of these materials in mortar mixture.

- It was found that mortar shrinkage reduces with an increase in replacement of cement with finely ground glass. The lowest shrinkage was measured in mortar WG35. The 5 to 10 percent addition of replacement CRT glass to mortar reduces mortar shrinkage by around $20 \%$.

\section{REFERENCES}

[1] Nakić, D., Vouk, D., Štirmer, N., Serdar, M.: Management of sewage sludge - new possibilities involving partial cement replacement, GRAĐEVINAR, 70 (2018) 4, pp. 277-286, https://doi. org/10.14256/JCE.2164.2017.

[2] Marinković, S., Protić, M., Paunović, S., Nešović, l., Bijeljić, J. (2018). Application of industrial by-products as mineral admixtures for self-compacting concrete, GRAĐEVINAR, 70 (2018) 1, pp. 31-38, https://doi.org/10.14256/JCE.1516.2015.

[3] Malešev, M., Radonjanin, V., Vukoslavčević, S., Supić, S., Laban, $\mathrm{M}$.: Influence of fly ash and decreasing water-powder ratio on performance of recycled aggregate concrete, GRAĐEVINAR, 69 (2017) 9, pp. 811-820, https://doi.org/10.14256/JCE.1379.2015.

[4] Her-Yung, W.: The effect of the proportion of thin film transistorliquid crystal display (TFT-LCD) optical waste glass as a partial substitute for cement in cement mortar, Constr. Build. Mater, 25 (2011), pp. 791-797, https://doi.org/10.1016/j. conbuildmat.2010.07.004

[5] Baldé, C.P., Wang, F., Kuehr, R., Huisman, J.: The global e-waste monitor - 2014, United Nations. University, IAS - SCYCLE, Bonn, Germany.

[6] Singh, N., Li, J., Zeng, X.: Global responses for recycling waste CRTs in e-waste, Waste Manage, 57 (2016), pp. 187-197, https://doi. org/10.1016/j.wasman.2016.03.013.
- Replacement of cement with CRT glass finer than $63 \mu \mathrm{m}$ in the amount of $35 \%$ by mass does not cause an alkali silicate reaction.

- On the basis of SEM analysis of mortar, it can be observed that texture compactness reduces with an increase in the share of replacement of cement with glass, making mortar texture more porous and rougher. On the other hand, the addition of $10 \%$ of glass as replacement for cement results in an almost unchanged texture of mortar, which leads to the conclusion that glass particles in the mortars with glass addition bind well with other mortar components.

- Generally speaking, taking into consideration all above mentioned test results, finely ground CRT glass can serve as an adequate replacement for a part of cement. It was established in the experiment that, up to $15 \%$ of cement replacement with CRT glass, no considerable reduction of mechanical properties should be expected, and that the durability of mortar will thus be preserved. On the other hand, an up to $10 \%$ addition of CRT glass improves both mechanical properties and durability of mortars.

\section{Acknowledgements}

Theworkreported in this paper is apartof theinvestigationconducted within the research project TR 36017 "Utilization of by-products and recycled waste materials in concrete composites in the scope of sustainable construction development in Serbia: investigation and environmental assessment of possible applications", which is backed by the Ministry for Science and Technology, Republic of Serbia. This support is gratefully acknowledged.

[7] Mear, F., Yot, P., Cambon, M., Ribes, M.: The characterization of waste cathode - ray tube glass, Waste Manage., 26 (2006), pp. 1468-1476, https://doi.org/10.1016/j.wasman.2005.11.017.

[8] Kamali, M., Ghahremaninezhad, A.: An investigation into the hydration and microstructure of cement pastes modified with glass powders, Constr. Build. Mater, 112 (2016), pp. 915-924, https://doi.org/10.1016/j.conbuildmat.2016.02.085.

[9] Manullang, R.J., Samadhi, T.W., Purbasari, A.: Formulation of portland composite cement using waste glass as a supplementary cementitious material, AIP Conference Proceedings 1887, 020040 (2017); 10.1063/1.5003523

[10] Shi, C., Zheng, K.: A review on the use of waste glasses in the production of cement and concrete, Resources, Conservation and Recycling, 52 (2007), pp. 234-247, https://doi.org/10.1016/j. resconrec.2007.01.013

[11] Aliabdo, A., Elmoaty, A., Aboshama, A.: Utilization of waste glass powder in the production of cement and concrete, Constr. Build. Mater, 124 (2016), pp. 866-877, https://doi.org/10.1016/j. conbuildmat.2016.08.016.

[12] Mafalda, A., Sousa-Coutinho, J.: Durability of mortar using waste glass powder as cement replacement, Constr. Build. Mater, 36 (2012), pp. 205-215, https://doi.org/10.1016/j. conbuildmat.2012.04.027 